\title{
PERANAN KEGIATAN MERONCE DENGAN BAHAN BEKAS DALAM MENINGKATKAN MOTORIK HALUS ANAK USIA 5-6 TAHUN
}

\author{
Gerli Yomima Ariska Tjaya ${ }^{1}$, Rosita Wondal $^{2}$, Haryati ${ }^{3}$ \\ Universitas Khairun Ternate \\ Fakultas Keguruan dan Ilmu Pendidikan \\ Jl. Bandarah Sultan Baabullah Kota Ternate Utara, Kotak Pos 53 Ternate 977328 \\ Telepon: (0921) 3110905-Faksimili 0921-3110901 \\ Email: gerlytjaya34@gmail.com ${ }^{1}$,rositawondal80@gmail.com ${ }^{2}$, \\ haryati.mansyur@gmail.com ${ }^{3}$
}

\begin{abstract}
Abstrak: Perkembangan fisik merupakan hal penting dalam kehidupan anak usia 5-6 tahun terutama perkembangan fisik motorik halus, sebagai langkah awal dalam menyiapkan anak untuk menulis. Dalam meningkatkan perkembangan motorik halus anak banyak aktivitas kelas yang membantu anak-anak dalam mengendalikan motorik halus guna menstimulasi syarafsyaraf otot anak agar berfungsi dengan baik. Aktivitas perkembangan motorik halus anak usia dini bertujuan untuk melatihkan ketrampilan koordionasi motorik anak diantaranya koordinasi antara tangan dan mata yang dapat dikembangkan melalui aktivitas bermain. Salah satu stimulus yang biasa dilakukan adalah melatih anak dalam memegang benda-benda kecil seperti pada kegiatan meronce. Dalam penelitian kajian pustaka ini penulis mengkaji tentang kegiatan meronce dalam meningkatkan motorik halus anak. Kegiatan meronce yang dikaji dengan menggunakan bahan-bahan yang sering ditemukan anak dalam kehidupan sehari-hari bahkan anak menggunakan bahan tersebut (bahan bekas) sehingga bahan-bahan tersebut tidak menjadi sampah yang membebani pemerintah. Berdasarkan kajian literatur yang dilakukan disimpulkan bahwa dengan kegiatan meronce dapat membantu anak untuk mengembangkan motorik halus.
\end{abstract}

Kata Kunci: Kegiatan meronce, Motorik halus

Abstract: Physical development is important for children aged 5-6 years, especially fine motor skills development, as a first step in preparing them to write.In improving fine motor skills, many class activities can be done by children to stimulate nerves of the child's muscles to function properly. The aim of this activity is to practice children's motor coordination skills include coordination between hands and eyes through play activities.One stimulus usually done is to train children in handling small objects such as meronce activities.In this literature study, the author examines meronce activities in improving children fine motor skills.Meronce activities are studied by used materials that are often found by children in their daily life and even children use these materials so that these materials do not become waste that burdens the government.Based on the literature review, it is concluded that meronce activities can help children to develop fine motor skills.

Key words: meronce, fine motor skills 


\section{A. Pendahuluan}

Anak usia dini merupakan usia yang sangat penting yang biasa dikenal dengan sebutan usia emas atau the golden age yang sangat potensial untuk melatih dan mengembangkan berbagai potensi kecerdasan yang dimiliki anak. Pendidikan anak usia dini telah dipandang sebagai sesuatu wadah yang sangat strategis dalam rangka menyiapkan generasi yang unggul dan tangguh, siap menghadapi masa depan bangsa merupakan generasi penentu perkembangan bangsa kedepan.

Pendidikan anak usia dini (PAUD) merupakan suatu upaya pembinaan yang ditujukan kepada anak sejak lahir sampai dengan usia enam tahun, yang dilakukan melalui pemberian rangsangan pendidikan untuk membantu pertumbuhan dan perkembangan jasmani dan rohani, agar anak memiliki kesiapan dalam memasuki pendidikan lebih lanjut. Anak usia dini yang mengecam pendidikan di lembaga PAUD mendapatkan sejumlah stimulasi guna mengembangkan aspek-aspek perkembangannya agar berfungsi optimal sesuai dengan usianya dilakukan dengan situasi yang menyenangkan (bermain).

Perkembangan pada anak meliputi aspek kognitif, aspek fisik (motorik), aspek bahasa dan komunikasi, aspek personal, sosial dan emosional, serta aspek moral dan spiritual. Perkembangan fisik merupakan hal penting dalam kehidupan anak terutama perkembangan fisik motorik halus, sebagai langkah awal dalam menyiapkan anak untuk menulis. Dalam meningkatkan perkembangan motorik halus anak banyak aktivitas kelas yang membantu anak-anak dalam mengendalikan motorik halus guna menstimulasi syaraf-syaraf otot anak agar berfungsi dengan baik.

Upaya yang dilakukan untuk meningkatkan kemampuan motorik halus anak ditekankan pada pengaktifan pembelajaran untuk membangun pengetahuan dan ketrampilan melalui pengalaman secara langsung. Salah satu kegiatan yang dapat menstimulus perkembangan motorik halus anak adalah dengan kegiatan meronce. Kegiatan meronce merupakan suatu kegiatan yang membutuhkan koordinasi antara mata dan tangan anak dalam memasukan benang pada lubang yang tersedia pada bahan roncehan. Jika otot-otot halus pada jemari anak belum lentur dan belum terkoordinasi dengan baik, anak akan mengalami kesulitan dalam kegiatan meronce. Jika kegiatan ini dilakukan secara kontinyu maka diharapkan anak akan trampil menggunakan otot-otot halusnya dalam menyelesaikan tugas-tugas perkembangannya. Faktor terbentuknya kemampuan motorik halus adanya stimulus yang berasal dari lingkungan salah satunya dengan suatu latihan / pembelajaran. Kegiatan yang dilakukan pada lembaga PAUD dikemas dalam suasana bermain melalui suatu kegiatan yang konkret dan pendekatan yang berorientasi bermain karena prinsip pada pembelajaran PAUD adalah bermain sambil belajar. Bermain sebagai bentuk kegiatan di PAUD meliputi kegiatan bermain kreatif dan menyenangkan bermain juga dapat membentuk belajar yang efektif karena dapat memberikan rasa senang. 
Aktivitas perkembangan motorik halus anak usia dini bertujuan untuk melatihkan ketrampilan koordionasi motorik anak diantaranya koordinasi antara tangan dan mata yang dapat dikembangkan melalui aktivitas bermain. WHO (2010) memberikan data bahwa 5-25 \% dari anak-anak usia pra sekolah menderita gangguan perkembangan motorik halus (Kementrian Kesehatan Republik Indonesia, 2012). Gangguan motorik pada usia pra sekolah diperkirakan dari 5-3\% dan sebanyak $60 \%$ dari kasus yang ditemukan terjadi secara spontan pada umur di bawah 5 tahun (Kementerian Kesehatan Republik Indonesia, 2012).

Erna Kusnita (2017) menyimpulkan bahwa terdapat peningkatan kemampuan motorik halus anak dengan kegiatan meronce dengan media manikmanik dalam kegiatan pembelajaran motorik halus dengan baik (43\%) pada siklus I dan pada siklus II terdapat peningkatan kemampuan motorik halus dalam kegiatan meronce dengan media manik-manik dengan sangat baik (88\%). Hasil penelitian yang dilakukan oleh Warniti dkk (2014) juga menunjukan bahwa hasil analisis data menunjukan bahwa terjadi peningkatan perkembangan motorik halus anak dengan diterapkannya metode pemberian tugas melalui kegiatan meronce pada hasil penelitian siklus I sebesar 53,95\% yang berada pada kategori sangat rendah ternyata mengalami peningkatan pada penelitian siklus II menjadi $80,7 \%$ yang berada pada kategori tinggi. Pada penelitian siklus I ke siklus II terjadi peningkatan sebesar 26,75\%. Dengan demikian dapat disimpulkan bahwa dengan menerapkan metode pemberian tugas melalui kegiatan meronce dapat meningkatkan perkembangan motorik halus pada anak kelompok B Semester II TK Tirta Kumara Payangan tahun pelajaran 2013/2014.

Pada usia 5-6 tahun anak sudah mampu melakukan aktifitas yang melibatkan kemampuan motoriknya, misalnya mengancingkan baju, menalikan sepatu, menggunting dengan rapi, mewarnai dan menggambar dengan hasil yang rapi serta menempel dengan masuk pada objek benda. Berdasarkan fakta di lapangan bahwa anak usia 5-6 tahun dalam memegang pensil (alat tulis) cenderung mengalami kesulitan. Masih terjadi kesalahan dalam menulis simbol-simbol abjad maupun angka. Hal ini terjadi karena otot-otot halus anak belum sepenuhnya berkembang dengan optimal. Melalui penelitian kajian literatur maka penulis tertarik untuk mengkaji tentang bagaimana pengembangan motorik halus anak usia 5-6 tahun. Dalam artikel ini penulis memberikan solusi bahwa dengan melakukan kegiatan meronce dapat membantu meningkatkan motorik halus anak.

\section{B. Pembahasan}

\section{Perkembangan Motorik Halus}

Motorik adalah terjemahan dari kata "motor" yang menurut Gallahue adalah suatu dasar biologi atau mekanika yang menyebabkan terjadinya suatu gerak. Gerak (movement) adalah kultimasi dari suatu tindakan yang didasari oleh proses motorik. Muhibbin juga menyebut motorik dengan istilah "motor". Menurutnya, motor diartikan sebagai istilah yang menunjukkan pada hal, keadaan, dan kegiatan yang melibatkan otot-otot juga gerakannya (Samsudin, 2007). 
Santrock (2007) menyatakan bahwa motorik halus adalah keterampilan menggunakan media dengan koordinasi antara mata dan tangan, sehingga gerakan tangan perlu dikembangkan dengan baik agar keterampilan dasar yang meliputi membuat garis horizontal, garis vertikal, garis miring ke kiri, atau miring ke kanan, lengkung atau lingkaran dapat terus ditingkatkan. Motorik halus merupakan gerakan yang menggunakan otot otot halus seperti menulis, melipat, menggunting dan lain sebagainya (Suyanto, 2005). Susanto (2011) motorik halus adalah gerakan halus yang melibatkan bagian-bagian tertentu saja yang dilakukan oleh otot-otot kecil saja, karena tidak memerlukan tenaga. Namun begitu gerakan yang halus ini memerlukan koordinasi yang cermat.

Keterampilan motorik halus sangat penting untuk membantu dalam kegiatan sehari-hari dan membantu anak dalam beradaptasi dengan pengalaman sehari-hari yang melibatkan aktivitas fisik. Perkembangan motorik halus meliputi keterampilan pergerakan jari tangan, keterampilan pergelangan tangan, dan keterampilan koordinasi mata dengan tangan (Aprianty,2018).

Soetjiningsih (1995) mengemukakan bahwa gerakan motorik halus yaitu gerakan yang melibatkan bagian-bagian tubuh tertentu saja dan dilakukan otot-otot kecil, tetapi diperlukan koordinasi yang cermat, contohnya: memegang benda kecil dengan jari telunjuk dan ibu jari, memasukkan benda kedalam botol, menggambar, dan lain-lain.

Pendapat Saputra (2005) menyatakan bahwa perkembangan motorik adalah suatu perubahan dalam perilaku motorik yang memperlihatkan interaksi dari kematangan makhluk dan lingkungannya. Pada manusia perkembangan motorik merupakan perubahan kemampuan motorik dari bayi sampai dewasa yang melibatkan berbagai aspek perilaku dan kemampuan motorik. Aspek perilaku dan perkembangan motorik saling mempengaruhi satu sama lain.

Jamaris (2006) mengungkapkan keterampilan koordinasi motorik atau otot halus menyangkut koordinasi gerakan jari-jari tangan dalam melakukan berbagai aktivitas. Aktivitas-aktivitas tersebut ada berbagai macam di antaranya yaitu:

a) Anak dapat menggunakan gunting untuk memotong kertas.

b) Anak dapat memasang dan membuka kancing dan resleting.

c) Anak dapat menahan kertas dengan satu tangan, sementara tangan yang lain digunakan untuk menggambar, menulis atau kegiatan lainnya.

d) Anak dapat memasukkan benang ke dalam jarum

e) Anak dapat mengatur (meronce) manik-manik dengan benang dan jarum.

f) Anak dapat melipat kertas untuk dijadikan suatu bentuk.

g) Anak dapat menggunting kertas sesuai dengan garis dan lain-lain.

Perkembangan fisik anak melibatkan dua wilayah koordinasi motorik penting yaitu gerakan yang dikendalikan oleh otot-otot besar atau kasar dan dikendalikan oleh otot-otot kecil atau halus. Motorik halus sangat penting karena berpengaruh pada segi pembelajaran lainnya. Motorik halus penting karena ini nantinya akan dibutuhkan anak dari segi akademis tersebut seperti 
menulis, menggunting, menciplak, meronce, mewarnai dan menganyam. Penguasaan motorik halus penting bagi anak, karena seiring makin banyak keterampilan motorik yang dimiliki anak semakin banyak pula sosial yang dapat dilakukan anak serta semakin baik prestasi disekolah. Guru Taman KanakKanak harus menciptakan suasana yang menyenangkan bagi anak dalam proses belajar mengajar, seperti kelengkapan media, memanfaatkan alam, membuat ide-ide dalam menciptakan permainan, dan juga metode guru yang bervariasi. Apalagi dalam proses pembelajaran motorik halus seperti menciplak, mewarnai, menjumput, membuat garis vertikal dan horizontal dan menganyam (Rakimahwati dalam Susanti 2018).

Adapun faktor-faktor yang mempengaruhi perkembangan motorik halus anak menurut Kartini Kartono (1995) adalah sebagai berikut:

a. Faktor hereditas (warisan sejak lahir atau bawaan).

b. Faktor lingkungan yang menguntungkan atau merugikan kematangan fungsifungsi organis dan fungsi psikis.

c. Aktivitas anak sebagai subjek bebas yang berkemauan, kemampuan, punya emosi serta mempunyai usaha untuk membangun diri sendiri.

Rumini dan Sundari (2004) juga mengemukakan bahwa faktor-faktor yang mempercepat atau memperlambat perkembangan motorik halus anak antara lain :

\section{a. Faktor Genetik}

Individu mempunyai beberapa faktor keturunan yang dapat menunjang perkembangan motorik misalnya otot kuat, syaraf baik, dan kecerdasan yang menyebabkan perkembangan motorik individu tersebut menjadi baik dan cepat.

b. Faktor kesehatan pada periode prenatal

Janin yang selama dalam kandungan dalam keadaan sehat, tidak keracunan, tidak kekurangan gizi, tidak kekurangan vitamin dapat membantu memperlancar perkembangan motorik anak.

c. Faktor kesulitan dalam melahirkan

Faktor kesulitan dalam melahirkan misalnya dalam perjalanan kelahiran dengan menggunakan bantuan alat vacum, sehingga bayi mengalami kerusakan otak dan akan memperlambat perkembangan motorik bayi.

d. Kesehatan dan gizi

Kesehatan dan gizi yang baik pada awal kehidupan pasca melahirkan akan mempercepat perkembangan motorik bayi.

e. Rangsangan 
Adanya rangsangan, bimbingan dan kesempatan anak untuk menggerakkan semua bagian tubuh akan mempercepat perkembangan motorik bayi.

f. Perlindungan

Perlindungan yang berlebihan sehingga anak tidak ada waktu untuk bergerak misalnya anak hanya digendong terus, ingin naik tangga tidak boleh dan akan menghambat perkembangan motorik anak.

g. Prematur

Kelahiran sebelum masanya disebut premature biasanya akan memperlambat perkembangan motorik anak.

h. Kelainan

Individu yang mengalami kelainan baik fisik maupun psikis, sosial, mental biasanya akan mengalami hambatan dalam perkembangannya.

i. Kebudayaan

Peraturan daerah setempat dapat mempengaruhi perkembangan motorik anak misalnya ada daerah yang tidak mengizinkan anak putri naik sepeda maka tidak akan diberi pelajaran naik sepeda roda tiga.

Sumantri (2005) menyatakan bahwa fungsi mengembangkan keterampilan motorik halus yaitu sebagai berikut:

1) Mampu memfungsikan otot-otot kecil seperti gerakan jari tangan.

2) Mampu mengkoordinasikan kecepatan tangan dengan mata.

3) Mampu mengendalikan emosi.

\section{Kegiatan Meronce}

Kegiatan meronce ditujukan untuk melatih koordinasi mata dan tangan anak. Memperoleh hasil roncean yang menarik tentu perlu terampil dan kreatif. Menurut Sumanto (2005) bahwa meronce merupakan cara pembuatan benda hias atau benda pakai yang dilakukan dengan menyusun bagian-bagian bahan berlubang atau yang sengaja dilubangi memakai bantuan benang, tali dan sejenisnya.

Sumantri (2005) meronce adalah salah satu contoh kegiatan pengembangan motorik halus di TK, kegiatan menguntai dengan membuat untaian dari bahan-bahan yang berlubang, disatukan dengan tali atau benang. Purnawanti (2011) juga menambahkan bahwa meronce merupakan kegiatan menggabungkan sesuatu dengan seutas tali. Kegiatan meronce dilakukan untuk membuat kalung atau benda lain yang sejenis. 
Hasil penelitian dari Bakti (2014) melalui meronce menggunakan tanah liat dapat meningkatkan keterampilan motorik halus anak kelompok B di TK Yayasan Masyithoh, Beran. Pada siklus I kegiatan meronce menggunakan bahan tanah liat dilakukan dengan menggunakan tali yang tidak dibakar diujungnya dan roncean bentuk kubus serta tabung, sedangkan pada siklus II dilakukan dengan menggunakan tali yang dibakar dan roncean bentuk bulat dan setengah lingkaran.

Warniti dkk (2014) melakukan penelitian dengan judul Penerapan Metode Pemberian Tugas Melalui Kegiatan Meronce Untuk Meningkatkan Perkembangan Motorik Halus Anak Kelompok B yang berjumlah 20 orang anak. Hasil analisis data menunjukan bahwa terjadi peningkatan perkembangan motorik halus anak dengan diterapkannya metode pemberian tugas melalui kegiatan meronce pada hasil penelitian siklus I sebesar 53,95 \% yang berada pada kategori sangat rendah ternyata mengalami peningkatan pada penelitian siklus II menjadi 80,7 \% yang berada pada kategori tinggi. Pada penelitian siklus I ke siklus II terjadi peningkatan sebesar 26,75\%. Dengan demikian dapat disimpulkan bahwa dengan menerapkan metode pemberian tugas melalui kegiatan meronce dapat meningkatkan perkembangan motorik halus pada anak kelompok B Semester II TK Tirta Kumara Payangan tahun pelajaran 2013/2014.

Mulyawartini (2019) melakukan penelitian dengan tujuan untuk mengetahui peningkatan kemampuan motorik halus anak melalui kegiatan meronce bentuk dan warna pada kelompok B TK Harapan kelayu kecamatan Selong tahun pelajaran 2016/2017. Penelitian ini merupakan penelitian tindakan kelas. Subjek penelitian ini adalah siswa kelompok B TK Harapan kelayu kecamatan Selong. Hasil penelitian menunjukkan peningkatan dari siklus I ke siklus II. Pada pelaksanaan pembelajaran dan hasil analisis data diperoleh skor ketuntasan klasikal sebesar $30 \%$ pada siklus I dan meningkat menjadi $90 \%$ pada siklus II. Aktivitas guru juga meningkat dengan nilai ratarata 3 meningkat menjadi 4 pada siklus II. Oleh karena itu, pembelajaran melalui kegiatan meronce bentuk dan warna dapat meningkatkan kemampuan motorik halus anak.

Berikut adalah beberapa gambar hasil meronce dari bahan sedotan dan tutup botol kemasan bekas. 


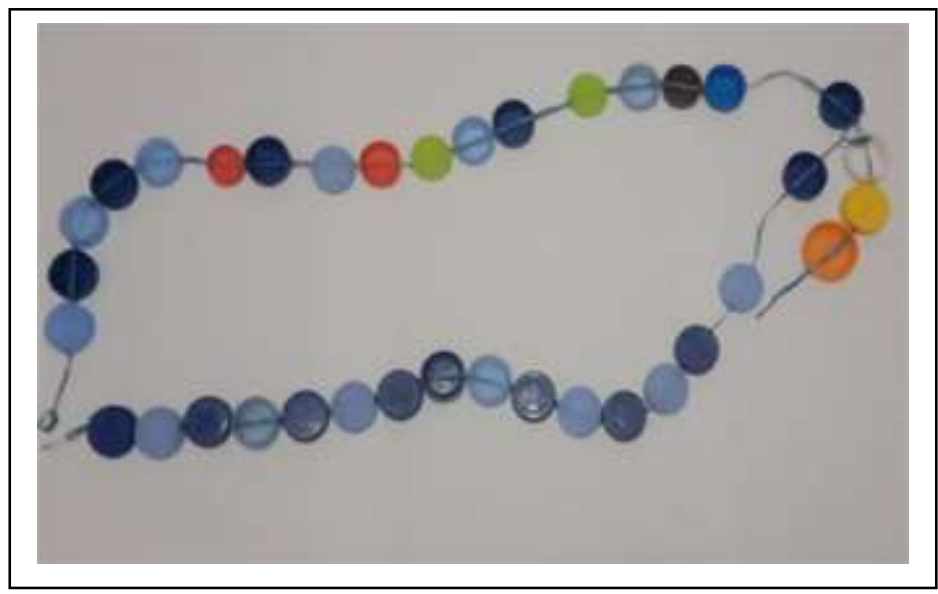

Gambar 1. Hasil Roncehan'Tirai' dari Bahan Bekas Tutup Botol Plastik

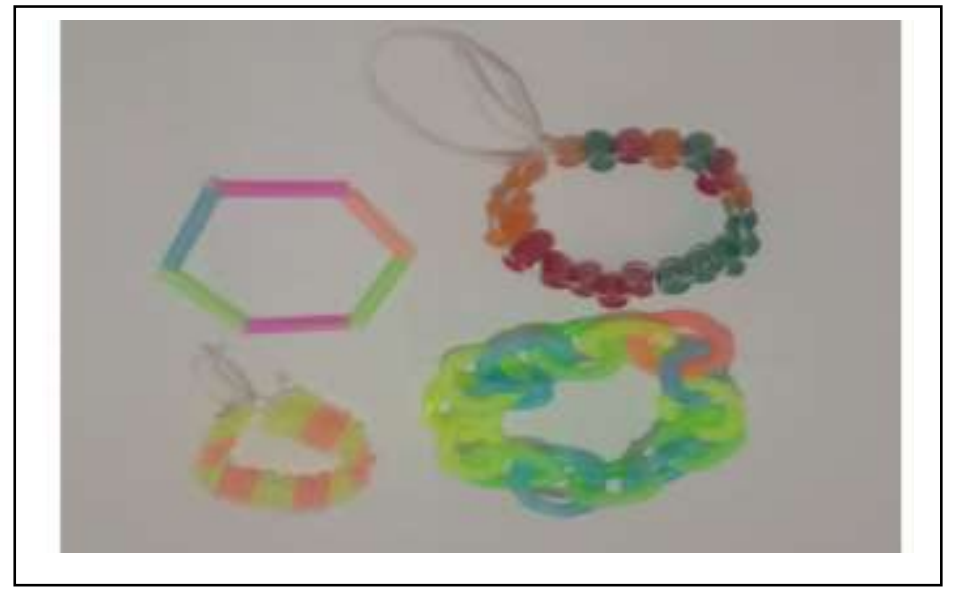

Gambar 2. Hasil Roncehan 'gelang' dari Bahan Bekas Sedotan Plastik 


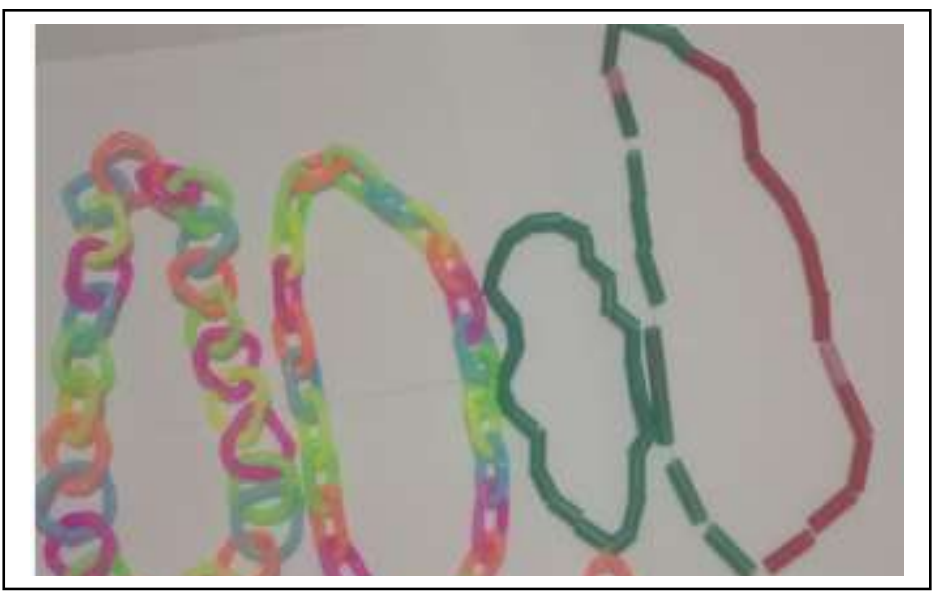

Gambar 1. Hasil Roncehan 'kalung' dari Bahan Bekas Sedotan Plastik

Bahan yang digunakan dalam kegiatan meronce dapat kita jumpai dalam kehidupan sehari-hari. Seperti pada gambar 1 dan 2, Peneliti menggunakan bahan-bahan bekas seperti sedotan plastik, tutup botol bekas seperti botol aqua dan lain sebagainya yang dapat dijumpai di tempat-tempat sampah, serta tali plastik. Untuk tutup botol bekas, peneliti sengaja membuat lubang dengan menggunakan besi yang dipanaskan terlebih dahulu. Setelah membuat lubang pada tutup botol, peneliti menginstruksikan pada anak untuk membuat roncehan dengan cara memasukan tali plastik kedalam botol yang telah dilubangi. Sedangkan untuk bahan sedotan bekas, peneliti sengaja menggunting sedotan dengan ukuran sekitar $15 \mathrm{~cm}$, dan anak meronce dengan mengaitkan setiap unjung pada sedotan yang tersedia. Adapun hasil roncehan dapat berupa kalung, gelang maupun gantungan pada dinding rumah. Hal ini sangat berguna bagi anak selain menimbulkan rasa kegembiraan dalam melakukan hasil roncehan, juga menjadi moment penting dalam rangka mempersiapkan tangan anak dalam menulis permulaan. Anak mampu mengkoordinasikan jemarinya dengan koordinasi mata yang baik anak dapat memasukan setiap benang pada lubang sedotan maupun tutup botol. Ketika kegiatan ini terjadi berulang maka otot tangan anak akan lentur ini merupakan modal besar bagi anak untuk trampil menulis permulaan berbagai simbol huruf dengan tingkat kesulitan tersendiri.

Berdasarkan kajian literatur dapat dihipotesiskan bahwa dengan kegiatan meronce dapat membantu anak untuk mengembangkan motorik halus. Apabila anak mampu melakukan kegiatan meronce dengan trampil, maka kemampuan motorik halus anak sebagai persiapan untuk menulis permulaan. 


\section{Karakteristik Perkembangan Motorik Halus Anak Usia 4-5 Tahun}

Masa anak usia dini sering disebut dengan istilah golden age atau masa emas. Menurut NAEYC dalam Sofia Hartati (2005) mengemukakan bahwa masamasa awal kehidupan tersebut sebagai masa-masanya belajar dengan slogannya sebagai berikut: "Early Years are Learning Years". Hal ini disebabkan karena pada masa anak usia dini anak mengalami pertumbuhan dan perkembangan yang sangat cepat, dimana potensi anak mengalami masa peka. Oleh karena itu diharapkan anak diberikan stimulus yang tepat agar dapat tumbuh dan bekembang dengan baik.

Perkembangan motorik pada anak Taman Kanak-kanak atau anak usia dini sangat memerlukan banyak frekuensi dan kesempatan untuk mengembangkan aktivitas fisik secara fundamental, misalnya berlari, melompat, melempar, mendorong, dan menarik. Aktivitas ini juga melatih konsentrasi gerak dalam koordinasi dengan indera yang lain (Harun Rasyid, 2009). Pendapat lain yang diungkapkan oleh Santrock (2007) perkembangan motorik anak TK yang masih berusia 4 tahun yaitu suka berpetualang dan memanjat dengan tangkas serta telah menunjukkan kemampuan atletis yang luar biasa. Di usia 5 tahun, anak semakin menyukai petualangan dibanding anak yang berusia 4 tahun. Anak berlari cepat dan menyenangi balapan satu sama lain dapat dengan orang tua maupun teman. Selama masa kanak-kanak tengah dan akhir, perkembangan motorik anak menjadi lebih halus dan lebih terkoordinasi dibandingkan ketika masih kanak-kanak awal.

Menurut Santrock (2007) kemampuan motorik halus anak usia 4 tahun, koordinasi motorik halus anak lebih tepat. Kadang anak berumur 4 tahun bermasalah dalam membangun menara tinggi dengan balok karena dengan keinginan mereka meletakkan setiap balok dengan sempurna, mereka membongkar lagi balok sudah tersusun. Saat berumur 5 tahun, koordinasi motorik halus anak sudah semakin meningkat. Tangan, lengan dan jari semua bergerak bersama dibawah perintah mata. Menara sederhana tidak lagi menarik minat anak, yang sekarang ingin membangun sebuah rumah dan gereja, lengkap dengan menaranya.

Karakteristik motorik halus anak usia 4-6 tahun dengan indikator Anak menunjukkan kelentukan otot dan mampu menolong diri sendiri menurut Sumantri (2005).

a. Dapat mengurus dirinya sendiri antara lain makan, berpakaian, mandi, menyisir rambut, mencuci dan melap tangan dll.

b. Dapat mengikat tali sepatu sendiri dengan sedikit bantuan atau sama sekali tanpa bantuan

c. Dapat membuat berbagai bentuk dengan menggunakan tanah liat, plastisin, playdough, seperti kue-kue dan sebagainya.

d. Meniru membuat garis tegak, garis datar dan lingkaran

e. Menirukan melipat kertas sederhana

f. Menggambar orang yang terdiri dari dua bagian (badan dan kepala) 
g. Belajar menggunting

h. Dapat menyalin lingkaran dan bujur sangkar

i. Menjahit sederhana.

Indikator perkembangan motorik halus anak usia 5-6 tahun menurut Peraturan Menteri Nasional Nomor 58 tahun 2009 adalah

Tabel 1. Pencapaian Perkembangan Motorik Halus Anak Usia 5-6 Tahun
\begin{tabular}{|l|l|}
\hline Aspek Perkembangan & Tingkat Pencapaian Perkembangan \\
\hline Motorik Halus & $\begin{array}{l}\text { 1. Menggambar sesuai gagasannya. } \\
\text { 2. Meniru bentuk. } \\
\text { 3. Melakukan eksplorasi dengan } \\
\text { berbagai media dan kegiatan. } \\
\text { 4. Menggunakan alat tulis dengan benar. } \\
\text { 5. Menggunting sesuai dengan pola. } \\
\text { 6. Menempel gambar dengan tepat. } \\
\text { 7. Mengekspresikan diri melalui gerakan } \\
\text { menggambar secara detail. }\end{array}$ \\
\hline
\end{tabular}

Secara khusus tujuan pengembangan motorik halus untuk usia TK (4-6 tahun) adalah anak dapat menunjukkan kemampuan menggerakkan anggota tubuhnya dan terutama terjadinya koordinasi mata dan tangan sebagai persiapan menulis. Pusat Kurikulum, Balit bang Departemen Pendidikan Nasional, (2002) mengungkapkan bahwa tujuan pengembangan motorik halus di usia 4-5 tahun adalah:

1) Mampu mengembangkan kemampuan motorik halus yang berhubungan dengan ketrampilan gerak kedua tangan.

2) Mampu menggerakkan anggota tubuh yang berhubungan dengan gerak jari jemari: seperti kesiapan menulis, menggambar, dan memanipulasi bendabenda.

3) Mampu mengkoordinasikan indra mata dan aktivitas tangan.

4) Mampu mengendalikan emosi dalam beraktivitas motorik halus. 


\section{KESIMPULAN}

Berdasarkan kajian literatur yang telah dikemukakan dapat disimpulkan bahwa dengan kegiatan meronce berperan dalam mengembangkan motorik halus. Selain mengembangkan motorik halus anak, kegiatan meronce juga yang dilakukan dapat mengurangi sampah dalam masyarakat. Pemanfaatan sampah dapat mengurangi pencemaran lingkungan sekitar anak. Oleh sebab itu melalui kajian ini disarankan oleh guru PAUD untuk memanfaatkan benda-benda bekas yang ada disekitar sebagai media untuk mengembangkan kemampuan anak kususnya perkembangan motorik halus anak.

\section{DAFTAR PUSTAKA}

ApriantyAsri, Makmuroh Sri Rahayu, Andhita Nurul Khasanah, (2018).The Influence of Slime Playing On Soft Motor Skills at Kindergarten Students B in As - Syiraj Kindergarten Bandung. Prosiding Psikologi. Volume 4, No. 2, Tahun 2018. ISSN: 2460-6448

Bakti Mumpuni Arum.(2014), Peningkatan Keterampilan Motorik Halus Melalui Kegiatan Meronce Menggunakan Bahan Tanah Liat Pada Kelompok B TK Yayasan Masyithoh Beran Bugel Kulon Progo. Skripsi Universitas Negeri Yogyakarta

Harun Rasyid, Mansur dan Suratno. (2009). Asesmen Perkembangan Anak Usia Dini. Yogyakarta: Multi Pressindo.

Hartati Sofia. (2005). Perkembangan Belajar Pada Anak Usia Dini. Jakarta: Departemen Pendidikan Nasional.

Jamaris Martini (2006). Perkembangan dan Pengembangan Anak Usia Taman KanakKanak. Jakarta: PT Grasindo

Kusnita Erna, (2017). Meningkatkan Kemampuan Motorik Halus Anak Melalui Kegiatan Meronce Dengan Media Manik-Manik Di Kelompok B Tk Aisyiyah Bustanul Athfal Bromo Medan. p-ISSN : 2355-1720 e-ISSN`: 2407-4926, SEJ VOLUME 7 NO. 1 JUNI 2017

Kartini Kartono, (1995), Psikologi Perkembangan, Bandung: PT. Mandar Maju

Kementrian Kesehatan Republik Indonesia. (2012). Profil kesehatan Indonesia tahun 2011. Jakarta: Kemenkes RI

Mulyawartini Gusti Ayu, (2019), Melalui Kegiatan Meronce Bentuk Dan Warna Dapat Meningkatkan Kemampuan Motorik Halus Anak Pada Kelompok B Tk Harapan Kelayu, Jurnal Edukasi dan Sains.vol 1 no 1 (2019): Agustus 
Susanti Meli, (2018). Peningkatan Kemampuan Motorik Halus Melalui Permainan Menganyam Dari Bahan Alam Di Taman Kanak - Kanak Cahaya Hati Kabupaten Pasaman Barat. JRTI (Jurnal Riset Tindakan Indonesia) Vol. 3 No. 2, 2018. hlm. 114-118 http://jurnal.konselingindonesia.com

Rakimahwati, R. (2017). Interactive Game Influences Based on Inquiry Learning

Purnawanti, Lina. 2011. Pintar Membuat Aksesoris. Bekasi: Laskar Aksara.

Model Towards The Ability of Reading in Kindergarten in Padang. In International Conference of Early Childhood Education (ICECE 2017). Atlantis Press.

Rumini Sri dan Siti Sundari, (2004), Perkembangan Anak dan Remaja, Jakarta: PT. Asdi Mahasatya

Santrock, John W. (2007). Perkembangan Anak Edisi ke Sebelas Jilid 1. (Med Mila Rachmawati). Jakarta: Penerbit Erlangga.

Sumantri, (2005).Model Pengembangan Keterampilan Motorik Anak Usia Dini. Jakarta : Universitas Terbuka. PT. Rineka Cipta.

Sumanto. (2005). Pengembangan Kreativitas Seni Rupa Anak TK. Jakarta: Departemen Pendidikan Nasional.

Susanto, Ahmad. (2011). Perkembangan anak usia dini. Jakarta : Kencana Prenada Media.

Saputra Yudha M. dan Rudyanto. (2005). Pembelajaran Kooperatif Untuk Meningkatkan Keterampilan Anak Taman Kanak-Kanak. Jakarta: Depdiknas.

Suyanto, (2005). Konsep Dasar Anak Usia Dini: Jakarta: Departemen Pendidikan Nasional.

Soetjiningsih. (1995). Tumbuh Kembang Anak. Jakarta: Penerbit Buku Kedokteran EGC.

Warniti Ni KD Surya, I Ketut Ardana, M.G.Rini Kristiantari, (2014). Penerapan Metode PemberianTugas Melalui Kegiatan Meronce Untuk Meningkatkan Perkembangan Motorik Halus Anak Kelompok B. e-Journal PG-PAUD Universitas Pendidikan Ganesha Jurusan Pendidikan Anak Usia Dini. Volume 2 No 1 Tahun 2014 